\title{
Nanopore sequencing for the detection and identification of Xylella fastidiosa subspecies and sequence types from naturally infected plant material
}

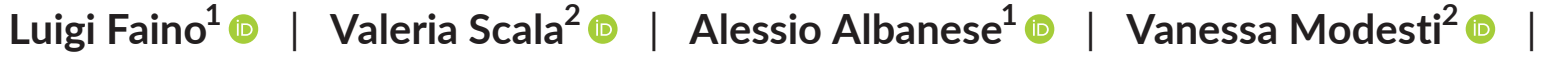

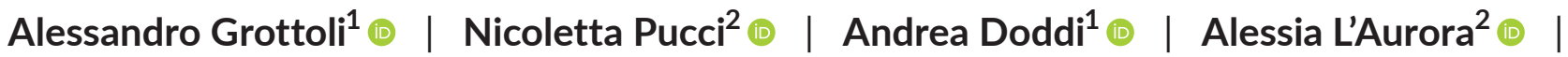

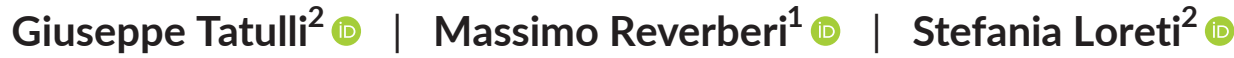

${ }^{1}$ Department of Environmental Biology, University of Rome, Rome, Italy

${ }^{2}$ Centro di Ricerca Difesa e Certificazione, Consiglio per la Ricerca in Agricoltura e I'Analisi dell'Economia Agraria, Rome, Italy

\section{Correspondence}

Luigi Faino, Dipartimento di Biologia

Ambientale, Università degli Studi di Roma

"La Sapienza", p.le Aldo Moro 5, Rome 00185, Italy.

Email: luigi.faino@uniroma1.it

Stefania Loreti, Centro di Ricerca Difesa e Certificazione, Consiglio per la Ricerca in Agricoltura e l'Analisi dell'Economia Agraria, Rome, Italy

Email: stefania.loreti@crea.gov.it

Funding information

Ministero delle Politiche Agricole Alimentari e Forestali: CO.XI.BO

("Controllo di parassiti e patogeni leg"):

Oli.Di.X.I.It ("OLIvicoltura e Difesa da Xylella")

\begin{abstract}
Xylella fastidiosa (Xf) is a gram-negative bacterial plant pathogen that can infect over 500 plant species. While it is endemic in America, $X$. fastidiosa subsp. pauca was reported for the first time in Europe in 2013 on olive trees in southern Italy. The availability of fast, sensitive, and reliable diagnostic tools is indispensable for managing current and future outbreaks of Xf. In this paper, we use the OXford Nanopore Technologies (ONT) MinION platform for detecting and identifying Xf at species, subspecies, and sequence type (ST) level. Two workflows were developed: the first one provided a "shotgun" strategy, that is, exploring the possibility of detecting Xf within DNA extracted from plant samples. This allowed detection of Xf by direct DNA sequencing and identifying the subspecies only in samples with high bacterial levels. Nanopore amplicon sequencing was pursued as a second workflow. This consists of PCR amplification of a set of seven multilocus sequence typing (MLST) fragments, officially adopted for identifying Xf at type strain level, followed by Nanoporesequencing of the amplicons and an ad hoc pipeline to generate MLST consensus calls. This combined approach, which takes only a few hours, allowed the detection and identification of $\mathrm{Xf}$ at ST level in plant material with low bacterial infection.
\end{abstract}

KEYWORDS

MinION, pathogen detection, Xylella fastidiosa

\section{1 | INTRODUCTION}

Xylella fastidiosa (Xf), a gram-negative phytopathogenic bacterium (Wells et al., 1987), has a very broad host range, causing different diseases in important crops (Hopkins, 1989) and in many urban shade trees (Sherald \& Kostka, 1992). Xf symptoms may not be evident and many hosts can carry symptomless infections, making this pathogen difficult to manage. The pathogen is transmitted by xylem sap-feeding insects and colonizes host xylem vessels, causing typical leaf scorching. $\mathrm{Xf}$ is an endemic pathogen in America and was only recently identified in southern Italy on olive trees (Saponari et al., 2013), in Corsica, and in the south-east Mediterranean coast

This is an open access article under the terms of the Creative Commons Attribution License, which permits use, distribution and reproduction in any medium, provided the original work is properly cited.

(c) 2021 The Authors. Plant Pathology published by John Wiley \& Sons Ltd on behalf of British Society for Plant Pathology 
of France on several hosts (Denancé et al., 2019). Subsequently, outbreaks of Xf were reported in Spain (Mallorca and Andalusia) in different plant species (Landa, 2017; Olmo et al., 2017) and in Portugal (EPPO, 2019a). Recently, a new occurrence was also reported in Tuscany, Italy (Marchi et al., 2018). Different Xf subspecies and sequence types (ST) were identified in Europe in association with the above-mentioned outbreaks. Based on DNA-DNA hybridization and recent comparative genomic analyses, three subspecies of $\mathrm{Xf}$ are recognized, namely fastidiosa, pauca, and multiplex (Denancé et al., 2019; Marcelletti \& Scortichini, 2016; Schaad et al., 2004). However, the International Society of Plant Pathology Committee on the Taxonomy of Plant Pathogenic Bacteria (ISPP-CTPPB) considers only the subsp. fastidiosa and subsp. multiplex as valid names, whereas other authors classify five subspecies (fastidiosa: Xff; pauca: Xfp; multiplex: Xfm; sandyi: Xfs; morus: Xfmo) (Bull et al., 2014; Nunney et al., 2012). Moreover, Xf subspecies include different sequence types (STs) that are determined by multilocus sequence typing (MLST) analysis based on the sequencing of seven housekeeping genes (EPPO, 2019b; Nunney et al., 2012; Yuan et al., 2010). MLST analysis is recommended for unambiguous identification of subspecies and ST in the case of a new outbreak or new plant hosts (EPPO, 2019b). Isolation of Xf is tedious, but the MLST analysis can be performed directly on DNA isolated from the host plant (EPPO, 2019b). However, a low concentration of the bacteria, and contaminants derived from the plant material, makes the MLST amplification, and thus subspecies and ST determination, extremely challenging (EPPO, 2019b).

Currently, next-generation sequencing (NGS) platforms represent high-throughput technologies that allow large data sets of genetic information to be obtained. In the biomedical field, sequencing technologies are rapidly becoming adopted for bacterial outbreak investigations (Faria et al., 2017) and for rapid clinical diagnostics (Votintseva et al., 2017). A combination of whole transcriptome amplification and Nanopore sequencing has been used to detect 'Candidatus Liberibacter asiaticus' and plum pox virus in plants and in insect vectors (Badial et al., 2018). The reliability of direct Nanopore sequencing for the diagnosis of several plant pathogens was demonstrated in artificially infected plants showing symptoms (Chalupowicz et al., 2019), and a rapid MLST determination method was described for ST estimation of Klebsiella pneumoniae isolates using Nanopore sequencing (Page \& Keane, 2018).

Diagnostic procedures under global trading have to be fast, reliable, and quantitative. Furthermore, the movement of pathogens and pests is becoming more prevalent thanks to globalization of commerce and global warming. The level of precision required to determine the species and to prevent its entrance into a pest-free area is currently at a maximum level. For bacteria at least, the identification should go down to subspecies or strain level, allowing effective control strategies to be designed promptly. In our study we propose a strategy that exploits OXford Nanopore Technologies (ONT) to diagnose emerging and invasive pathogens such as Xf. For this, we investigated two strategies: one relies on a shotgun approach, that is, direct sequencing of plant extracts, and the other on amplicon sequencing. The latter was the most reliable and robust strategy for subspecies and ST determination.

\section{2 | MATERIALS AND METHODS}

\section{1 | Sample preparation}

Four data sets were prepared as follows. The first data set (Set 1) consisted of 21 DNA samples extracted from naturally infected olive plants (Olea europea) collected in the Apulia region of southern Italy. Leaf samples collected as described by Scortichini et al. (2018) were crushed in a plastic bag (Bioreba) containing $5 \mathrm{ml}$ of Food Lysis Buffer from the DNeasy mericon Food Kit (50) (Qiagen) and DNA extraction was performed following the PM 7/24 (4) (EPPO, 2019b). Set 2 consisted of naturally infected samples of Spartium junceum, Polygala myrtifolia, Rosmarinus officinalis, Rhamnus alaternus, Prunus amygdalus, Cistus spp., and Lavandula spp., collected in Tuscany. Set 3 consisted of DNA from healthy olive trees collected in Latium, Italy, spiked with a known concentration of DNA from Xfp strain CFBP 8402. A pure culture of Xfp strain CFBP 8402, isolated from olive in Apulia region, was grown for $7-10$ days at $28{ }^{\circ} \mathrm{C}$ on buffered charcoal yeast extract ( $B C Y E$ ) agar. The culture was then scraped from the plate and resuspended in $100 \mu \mathrm{l}$ of phosphate buffer (PB) and grown in $10 \mathrm{ml}$ of PD2 broth at $28{ }^{\circ} \mathrm{C}, 170 \mathrm{rpm}$ for $7-10$ days up to a suspension of $\mathrm{OD}_{600}=0.8$. The bacterial DNA was extracted from $700 \mu \mathrm{l}$ of culture medium using the Gentra Puregene Yeast/Bact Kit (Qiagen). DNA from healthy olive leaves was extracted as reported below. The sample was collected from an olive plant located in a pest-free area in Rome and previously screened for the absence of $\mathrm{Xf}$ by real-time PCR (Harper et al., 2010). DNA concentration was quantified with a DS-11 FX+spectrophotometer (DENOVIX). DNA (about $40 \mathrm{ng} / \mu \mathrm{l}$ ) of healthy olive samples was amended with 100,10 , 8, or $4 \mathrm{fg}$ of Xfp DNA per PCR, each in three independent replicates. These Xf DNA concentrations were chosen as they corresponded to values close to the detection limit of real-time PCR, estimated according to Modesti et al. (2017), and equivalent to $10 \mathrm{fg} / \mathrm{PCR}$ for the real-time PCR of both Harper et al. (2010) and Francis et al. (2006).

The last data set, Set 4 , consisted of one healthy sample of different plant species collected in an $\mathrm{Xf}$-free area from Latium region. DNA extraction of plant material from Sets 2, 3, and 4 were performed with the CTAB-based method as reported in PM7/24 (4) (EPPO, 2019b).

\section{2 | Real-time PCR and MLST}

TaqMan real-time PCR (Harper et al., 2010) was performed using $1 \mu \mathrm{l}$ of total DNA in a final volume of $11 \mu \mathrm{l}$ (Loreti et al., 2017), and TaqMan real-time PCR (Francis et al., 2006) using $1 \mu$ l of total DNA in a final volume of $10 \mu \mathrm{l}$. The TaqMan Fast Universal Master Mix, no AmpErase UNG (Applied Biosystems), and TaqMan Universal PCR Master Mix (ThermoFisher Scientific, $2 \times$ ) were used for real-time 
PCR according to Harper et al. (2010) and Francis et al. (2006), respectively. These two real-time PCRs are currently used for the detection of $\mathrm{Xf}$ and both are considered reliable methods based on a recent EPPO validation report (Saponari \& Loconsole, 2018). All samples were also tested by real-time PCR as described by Li et al. (2013), following PM7/24 (4) (EPPO, 2019b) to confirm the bacterial infection. MLST analysis was performed on Cystus, Lavandula, and Rosmarinus as previously described (EPPO, 2019b; Yuan et al., 2010) and following PM7/24 (4) (EPPO, 2019b). For Nanopore amplicon sequencing, the amplification of housekeeping genes was modified by increasing the number of PCR cycles from 35 to 40 and by using Immolase DNA polymerase (Bioline).

\section{3 | Data sets used for Nanopore sequencing}

Direct Nanopore DNA sequencing was performed on Sets 1, 2, and 3 (Tables 1-3). Set 3 was used to test the direct DNA Nanopore sequencing near the limit of detection (LoD) of the real-time PCR (Table 3). DNA samples from Sets 2, 3, and 4 were used for Nanopore amplicon sequencing of the two genes cys $G$ and malF. Three out of seven samples from Set 2 (i.e., Cystus, Lavandula, and Rosmarinus) were assessed with Nanopore amplicon sequencing for all seven housekeeping genes.

\subsection{Nanopore sequencing}

Nanopore sequencing libraries were prepared according to the manufacturer's instructions for the kit SQK-RBK004 for both direct DNA and amplicon sequencing and sequenced on a R9.4.1 flowcell on a Mk1B device (Oxford Nanopore Technologies). In brief, about 400 ng DNA was purified using AMPure beads, ligated to the indexing adapter, combined in one sample, and subsequently ligated to the RAP adapter prior to sequencing. For amplicon sequencing, PCR amplicons of each sample were pooled and purified using Isolate II PCR and gel Kit (Bioline) and about 100 ng DNA was used for library preparation. DNA samples were run on the Nanopore flowcell v. 9.4.1 until pore life ended, while amplicon sequencing runs were performed for shorter time spans (c.5 hr). After sequencing, Deepbinner (v. 0.2.0) (Wick et al., 2018) was used to demultiplex the samples using default parameters. Subsequently, basecalling and

TAB LE 1 Direct Nanopore sequencing of Xylella fastidiosa (Xf) DNA in naturally infected olive samples collected in the Apulia region in Italy (data Set 1)

\begin{tabular}{|c|c|c|c|c|c|c|}
\hline Sample & $C_{t}^{a}$ & $\mathrm{Mb}$ & $\begin{array}{l}\text { No. of } \\
\text { reads }\end{array}$ & $\begin{array}{l}\text { No. of reads } \\
\text { mapped (\%) }\end{array}$ & $\begin{array}{l}\text { No. of reads mapping } \\
\text { to bacteria }(\%)^{c}\end{array}$ & $\begin{array}{l}\text { No. of reads } \\
\text { mapping to } X f(\%)^{d}\end{array}$ \\
\hline Olive-1 & 21.28 & 140.47 & 46,444 & 41,478 (89.3) & 755 (1.8) & $111(14.7)$ \\
\hline Olive-3 & 21.92 & 113.07 & 34,789 & 31,012 (89.1) & $556(1.8)$ & $49(8.8)$ \\
\hline Olive-4 & 25.7 & 100.87 & 44,308 & $39,342(88.8)$ & 539 (1.4) & $5(0.9)$ \\
\hline Olive-6 & 25.3 & 68.11 & 33,152 & $28,773(86.8)$ & 384 (1.3) & $6(1.6)$ \\
\hline Olive-7 & 27.85 & 107.05 & 39,608 & $34,853(88.0)$ & $537(1.5)$ & $9(1.7)$ \\
\hline Olive-8 & 27.24 & 95.05 & 33,240 & $29,871(89.9)$ & 525 (1.8) & $2(0.4)$ \\
\hline Olive-9 & 27.74 & 102.02 & 39,916 & $35,393(88.7)$ & 580 (1.6) & $12(2.1)$ \\
\hline Olive-10 & 35.3 & 43.94 & 17,468 & $15,383(88.1)$ & $213(1.4)$ & $0(0.0)$ \\
\hline Olive-14 & 26 & 111.75 & 42,884 & $37,284(86.9)$ & 538 (1.4) & 61 (11.3) \\
\hline Olive-15 & 34.5 & 87.21 & 34,260 & 29,717 (86.7) & $448(1.5)$ & $1(0.2)$ \\
\hline Olive-16 & 33.75 & 94.79 & 42,478 & $36,246(85.3)$ & 480 (1.3) & $0(0.0)$ \\
\hline Olive-17 & 31.6 & 31.19 & 10,868 & $9,586(88.2)$ & $131(1.4)$ & $0(0.0)$ \\
\hline Olive-18 & 30.1 & 101.70 & 43,913 & $37,632(85.7)$ & 475 (1.3) & $3(0.6)$ \\
\hline Olive-19 & 25.3 & 81.98 & 28,591 & 24,781 (86.7) & 402 (1.6) & $22(5.5)$ \\
\hline Olive-20 & 36 & 128.11 & 37,611 & $33,844(90.0)$ & $543(1.6)$ & $0(0.0)$ \\
\hline Olive-21 & 29 & 106.21 & 35,496 & $31,236(88.0)$ & 540 (1.7) & $4(0.7)$ \\
\hline
\end{tabular}

${ }^{a}$ Cycle threshold obtained by Harper et al. (2010), TaqMan version.

${ }^{\mathrm{b}}$ Percentage of reads mapped to bacterial species and Olea europaea over the number of total reads sequenced.

${ }^{\mathrm{c}}$ Percentage of reads mapped to bacterial species from the total mapped.

${ }^{\mathrm{d}}$ Percentage of reads mapped to $\mathrm{Xf}$ over the number of reads mapped to bacterial species. 
TAB LE 2 Direct Nanopore sequencing of Xylella fastidiosa (Xf) DNA in naturally infected plant samples collected in the Tuscany region in Italy (data Set 2)

\begin{tabular}{|c|c|c|c|c|c|c|}
\hline Sample & $C_{t}^{a}$ & $\mathrm{Mb}$ & $\begin{array}{l}\text { No. of } \\
\text { reads }\end{array}$ & $\begin{array}{l}\text { No. of reads } \\
\text { mapped }(\%)^{b}\end{array}$ & $\begin{array}{l}\text { No. of reads mapping } \\
\text { to bacteria }(\%)^{c}\end{array}$ & $\begin{array}{l}\text { No. of reads mapping } \\
\text { to Xf }(\%)^{d}\end{array}$ \\
\hline Prunus amygdalus & 27.35 & 122.78 & 114,327 & $11,508(10.1)$ & $7,621(66.2)$ & $22(0.3)$ \\
\hline Cystus sp. & 25.78 & 606.32 & 199,423 & $5,156(2.6)$ & $3,522(68.3)$ & $230(6.5)$ \\
\hline Rosmarinus officinalis & 33.00 & 247.79 & 182,831 & $9,657(5.3)$ & $4,662(48.3)$ & $2(0.1)$ \\
\hline Polygala myrtifolia & 25.10 & 184.91 & 87,762 & 11,447 (13.0) & $6,157(53.8)$ & $104(1.7)$ \\
\hline Spartium juceum & 18.61 & 286.19 & 155,150 & $10,919(7.0)$ & $6,650(60.9)$ & $1,699(25.5)$ \\
\hline
\end{tabular}

${ }^{a}$ Cycle threshold obtained by Francis et al. (2006), TaqMan version.

${ }^{b}$ Percentage of reads mapped to bacterial species and Olea europaea over the number of total reads sequenced.

${ }^{\mathrm{C}}$ Percentage of reads mapped to bacterial species from the total mapped.

${ }^{\mathrm{d}}$ Percentage of reads mapped to $\mathrm{Xf}$ genomes over the number of reads mapped to bacterial species.

TAB LE 3 Direct Nanopore sequencing of DNA from healthy olive samples spiked with a known concentration of DNA from Xylella fastidiosa (Xf) subsp. pauca CFBP 8402 (data Set 3)

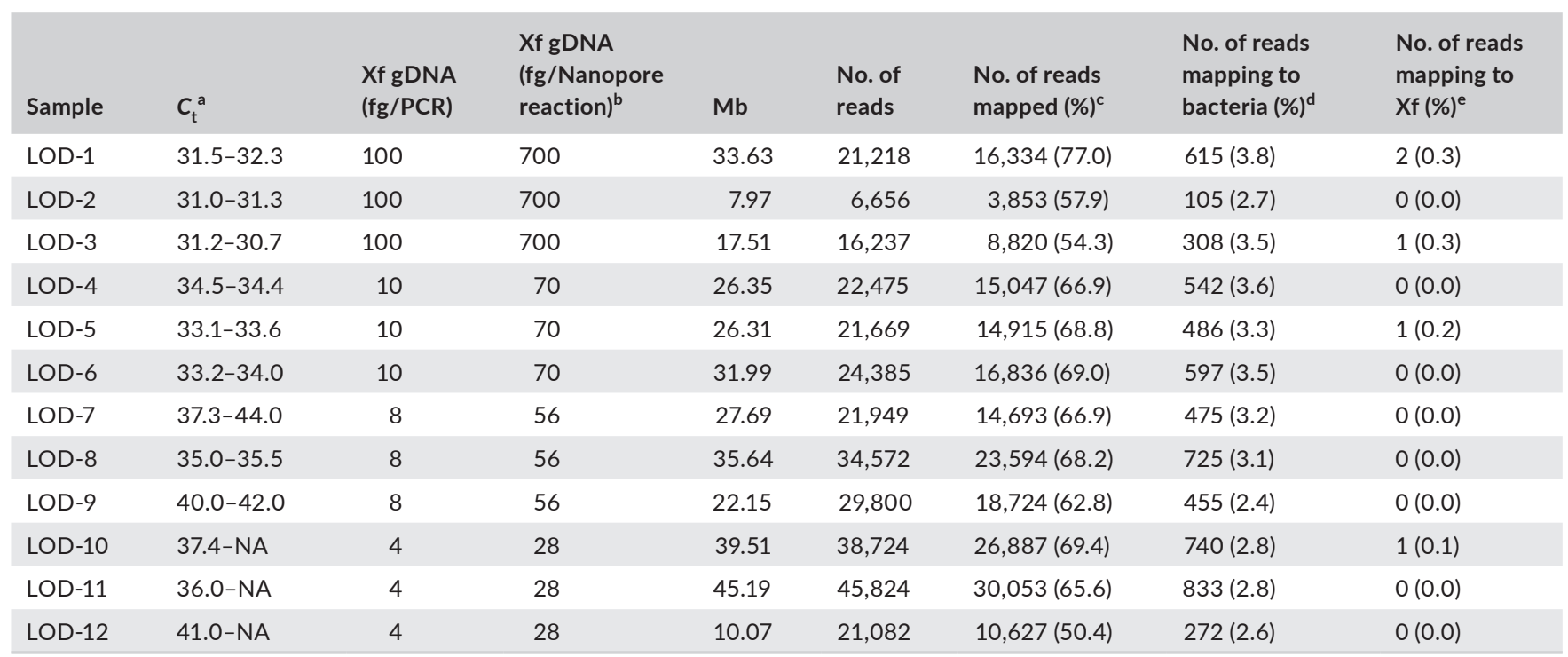

${ }^{a}$ Cycle threshold obtained by Francis et al. (2006), TaqMan version. The value reports the $C_{t}$ interval for the three technical replicates used for each sample. NA, low concentrate samples gave technical replicates with no $C_{t}$ value.

${ }^{\mathrm{b}}$ Total amount of Xf subsp. pauca gDNA added to Olea europaea gDNA and used for Nanopore sequencing.

'Percentage of reads mapped to bacterial species and O. europaea over the number of total reads sequenced.

${ }^{\mathrm{d}}$ Percentage of reads mapped to bacterial species from the total mapped.

${ }^{\text {e}}$ Percentage of reads mapped to $\mathrm{Xf}$ over the number of reads mapped to bacterial species.

a new run of demultiplexing was performed using Guppy (v. 2.3.1; default parameters) (Wick et al., 2019). Deepbinner and guppy basecalling were performed on a GPU card Nvidia GTX 10708 Gb.

\section{5 | Pipeline for gDNA Xf detection: detection_ script}

Reads generated with the two-step debarcoding analysis were analysed using a custom pipeline. In brief, reads were mapped to a database by using Minimap2 software (v. 2.17-r941; Li, 2018) using
--MD and --secondary=no as additional parameters. The mapping was split into two steps: the first step aligned all the reads against a database that includes one representative genome for all sequenced bacterial species (about 11,000 bacterial genomes) present in the NCBI GenBank database (https://www.ncbi.nlm.nih.gov/), while the second step aligned all reads mapped to $\mathrm{Xf}$ in the first step to an Xf-specific database that comprises approximately 60 genomes. For both steps, alignment output files were parsed to retrieve only the best match for reads mapping to multiple genomes. Finally, the number of reads mapping to the same subspecies/strains were combined and summarized in a plot (https://github.com/lfaino/xylella). 


\section{6 | MLST consensus generation: consensus_ script}

A second pipeline was written in order to generate MLST consensus after Nanopore sequencing. Briefly, reads from Nanopore sequencing were demultiplexed by using Deepbinner software $v$. 0.2.0 (Wick et al., 2018). Subsequently, porechop software v. 0.2.4 was used to remove adapters from the kept reads. Two rounds of read-correction by racon software v. 1.3.3 (Vaser et al., 2017) were performed. The corrected reads were passed to jellyfish software $v$. 2.2.8 (Marçais \& Kingsford, 2011) and reads of 100 nucleotides (nt) were generated. These reads were assembled by SPADES software v. 3.12.0 (Bankevich et al., 2012) and the assembled contigs polished by Nanopolish v. 0.11.1 and subsequently by bcftools mpileup software v. 1.7.2 (Danecek \& McCarthy, 2017). The reconstructed MLST sequences were compared to all other MLST deposited at https:// pubmlst.org/ (Jolley et al., 2018). The script used for MLST reconstruction can be found at GitHub (https://github.com/lfaino/xylella).

\section{3 | RESULTS}

\subsection{Detection and identification of $\mathrm{Xf}$ in infected plant material by direct Nanopore sequencing}

Direct Nanopore sequencing was assessed to detect Xf in naturally infected plants by using the ONT MinION device. The assay was first performed on DNA of 21 olive samples (Set 1) and of seven samples from different plant species (Set 2), making a total of 28 $\mathrm{Xf}$ naturally infected samples. All samples were also analysed by real-time PCR, which revealed a variable level of infection among samples. For example, in samples of Set $1, C_{t}$ values ranged from 21.28 to 36.17 , indicating a difference of about $10^{5}$ times between the most infected (Olive-1) and the least infected (Olive-11) sample (Table 1). The direct Nanopore sequencing was performed in three batches; the first one included samples Olive-1 to Olive-12, the second one samples from Olive-13 to Olive-21 of Set 1 (Table 1), and the third was composed of the seven infected samples from various plant species making up Set 2 (Table 2). All samples were barcoded individually before combining into a single sample for sequencing. The first flowcell generated approximately $3.2 \mathrm{~Gb}$ of data for the first batch of 12 samples in a run of $14 \mathrm{hr}$, the second flowcell produced approximately $2.7 \mathrm{~Gb}$ for the remaining nine olive samples in Set 1 in around $30 \mathrm{hr}$, while the third flowcell generated approximately $5.5 \mathrm{~Gb}$ for Set 2 in around $30 \mathrm{hr}$. All these flowcells were stopped before reaching the $48 \mathrm{hr}$ maximum running time due to pore saturation. Next, the sequencing data batches were subjected to demultiplexing based on the individual barcodes, and we were able to retain approximately $1.3 \mathrm{~Gb}$ and $800 \mathrm{Mb}$ of data for the two batches from Set 1 ( $40 \%$ and $30 \%$ of the total reads, respectively), and approximately $2 \mathrm{~Gb}$ of data for Set 2 . The amount of data for the individual samples ranged from approximately $600 \mathrm{Mb}$ in the Cystus spp. sample to approximately $10 \mathrm{Mb}$ in Olive-17, illustrating high variability between samples, even though similar amounts of input gDNA were used (Tables 1 and 2). Each sample was analysed using a custom python script (called detection_script; see Materials and Methods) in order to identify Xf. Twenty-two out of 28 samples showed reads that map uniquely to the genome of Xylella spp. (Tables 1 and 2). With the flowcell throughput achieved in our work, all samples with no reads related to the $\mathrm{Xf}$ genome had a $C_{t}$ value $>31$ in the real-time PCR assays (Tables 1 and 2). To better assess the sensitivity of the direct Nanopore DNA sequencing, we prepared 12 samples of uninfected olive DNA spiked with a known concentration range of DNA of Xfp strain CFBP 8402 close to the detection limit of real-time PCR according Modesti et al. (2017) (Set 3; Table 3). A new Nanopore flowcell was used to sequence the samples of Set 3 , generating approximately $667 \mathrm{Mb}$ of data in $22 \mathrm{hr}$. The amount of data per sample ranged from $45 \mathrm{Mb}$ to $7.9 \mathrm{Mb}$ and Xfp was identified in only four samples using the detection_script (Table 3). These data show that direct DNA sequencing with Nanopore falls short in sensitivity when compared with real-time PCR.

\section{2 | Nanopore amplicon sequencing}

In order to increase the sensitivity of Nanopore sequencing for the detection of Xf, we pursued PCR-based amplification of Xf-specific targets followed by MinION sequencing of the amplicons. To this end, we used cys $G$ and malF primer sets as suggested in the PM7/24 (4) (EPPO, 2019b) for the subspecies identification. PCR amplification followed by MinION sequencing was performed on the spiked DNA set (Set 3) to check the assay sensitivity. cysG and malF amplicons of the spiked samples were tagged with barcodes and sequenced on MinION. The MinION device generated about $290 \mathrm{Mb}$ of data for all 12 samples combined, and after demultiplexing, we retained approximately $155 \mathrm{Mb}$ of data. The number of reads per sample ranged from 14,360 to 54,405 for LOD-10 and LOD-2, respectively (Table 4). The detection_script was used to detect Xf in each sample. The number of reads matching uniquely to a bacterial genome varied from $3.39 \%$ in sample LOD-9 to $50.35 \%$ in sample LOD-5 (Table 4). As expected, $>95 \%$ of those reads mapped to Xf (Table 4, Figure 1). The only exception was sample LOD-9, for which a low number of reads mapped to bacterial genomes, suggesting amplification problems (Table 4, Figure 1). Our findings showed that Nanopore-based detection of $\mathrm{Xf}$ based on amplicon sequencing detected the majority of the samples of Set 3 , including samples (from LOD-7 to LOD-12) that were not correctly detected or were not reproducible by real-time PCR (Table 4).

We reasoned that by correcting Nanopore sequencing errors, because the same region is sequenced multiple times, we can produce a more accurate sequence that allows us to identify Xf at the subspecies level. To validate this, we used the detection_script in combination with a specific Xf database formed by every Xf genome available in the NCBI database (c.60 genomes). For all 11 positive samples of Set 3, >95\% of the reads correctly mapped to a genome of Xfp (Figure 2). To further validate this approach, the same 


\begin{tabular}{|ccccc|}
\hline Sample & Mb & $\begin{array}{l}\text { No. of } \\
\text { reads }\end{array}$ & $\begin{array}{l}\text { No. of reads mapping to } \\
\text { bacteria (\%) }\end{array}$ & $\begin{array}{c}\text { No. of reads mapping } \\
\text { to X. fastidiosa (\%) }\end{array}$ \\
\hline LOD-1 & 1.95 & 42,384 & $16,543(39.0)$ & $16,367(98.9)$ \\
\hline LOD-2 & 2.50 & 54,405 & $26,119(48.0)$ & $25,870(99.0)$ \\
\hline LOD-3 & 1.00 & 21,805 & $7,765(35.6)$ & $7,689(99.0)$ \\
\hline LOD-4 & 1.37 & 29,806 & $12,039(40.4)$ & $11,866(98.6)$ \\
\hline LOD-5 & 1.72 & 37,384 & $18,827(50.4)$ & $18,683(99.2)$ \\
\hline LOD-6 & 1.89 & 40,984 & $7,347(17.9)$ & $7,163(97.5)$ \\
\hline LOD-7 & 1.04 & 22,675 & $3,147(13.9)$ & $2,794(88.8)$ \\
\hline LOD-8 & 1.02 & 22,087 & $5,403(24.5)$ & $4,669(86.4)$ \\
\hline LOD-9 & 1.20 & 24,336 & $832(3.4)$ & $2(0.2)$ \\
\hline LOD-10 & 0.66 & 14,360 & $4,687(32.6)$ & $4,394(93.7)$ \\
\hline LOD-11 & 0.68 & 14,710 & $4,867(33.1)$ & $4,659(95.7)$ \\
\hline LOD-12 & 1.21 & 26,334 & $12,336(46.8)$ & $12,124(98.3)$ \\
\hline Control & $N A$ & 4,987 & - & $0(0)$ \\
\hline
\end{tabular}

TABLE 4 Nanopore amplicon sequencing of cys $G$ and malF amplified from DNA of healthy olive samples spiked with known amounts of Xylella fastidiosa subsp. pauca strain CFBP 8402 DNA (data Set 3)

aPercentage of reads mapped to bacterial species over the number of total reads sequenced.

${ }^{b}$ Percentage of reads mapped to $X$. fastidiosa over the number of reads mapped to bacterial species.

${ }^{\mathrm{c} N o n i n f e c t e d ~ O l e a ~ e u r o p a e a .}$

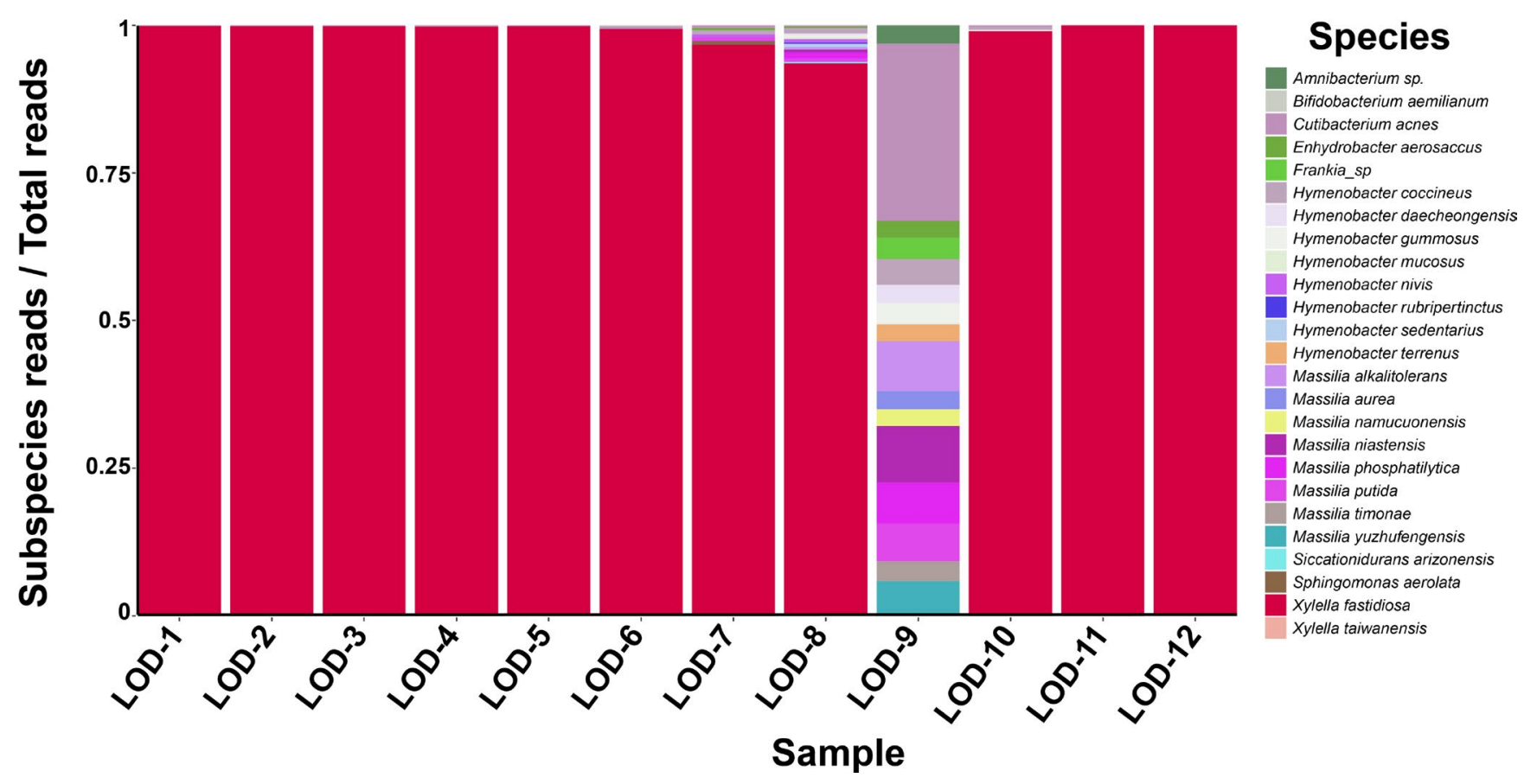

FIGURE 1 Stacked bar charts showing the relative abundance of bacterial species compared with Xylella fastidiosa using the detection_ script on Nanopore amplicon sequencing of olive DNA spiked with known concentrations of $X$. fastidiosa subsp. pauca DNA (Set 3)

procedure (amplification of cysG and malF, Nanopore sequencing, querying the $\mathrm{Xf}$-customized database) was used on samples of Sets 2 and 4 , the gDNA from different naturally infected plant species and uninfected samples, respectively (Table 5, Figure 3). For all samples in Set 2, except for R. alaternus, more than $35 \%$ of the amplicon-derived reads mapped to Xf (Table 5). Additionally, the analysis using the Xf-specific database showed that $>90 \%$ of the reads mapped to the $\mathrm{Xfm}$ genome, including $R$. alaternus (Figure 3 ). No $X f$ reads were identified by sequencing the amplicons of the healthy samples (Set 4; Table 5). To further support the subspecies identification results, we generated a consensus for the cys $G$ and malF sequences using the consensus_script. These consensus sequences were aligned to the $\mathrm{Xf}$-specific database, matching $100 \%$ to the multiplex subspecies (Figure 3). This identification corresponds to the recent study of Marchi et al. (2018) on the occurrence of $\mathrm{Xfm}$ in Tuscany. These results highlight that Nanopore amplicon sequencing can detect $\mathrm{Xf}$ in naturally infected samples at subspecies level. 


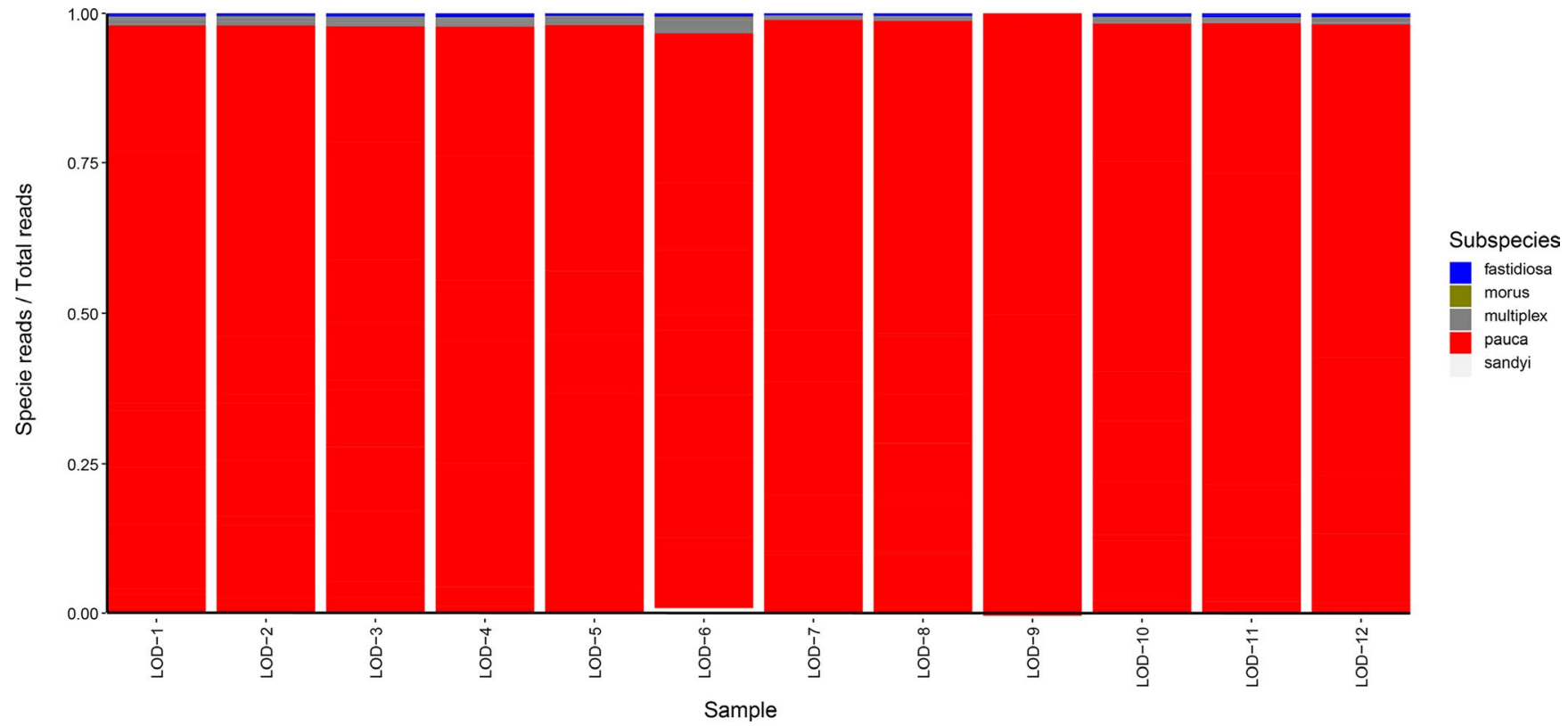

FIGURE 2 Stacked bar charts showing the relative abundance of Xylella fastidiosa subsp. pauca compared to other X. fastidiosa subspecies using the detection_script on Nanopore amplicon sequencing of olive DNA spiked with known concentrations of $X$. fastidiosa subsp. pauca DNA (Set 3). The most abundant subspecies is $X$. fastidiosa subsp. pauca

TABLE 5 Nanopore amplicon sequencing of cys $G$ and malF amplified from DNA of naturally infected plants samples collected in Tuscany region, Italy (data Set 2) and from healthy samples of different plant species collected in Latium region (data Set 4)

\begin{tabular}{|c|c|c|c|c|c|}
\hline Sample & $\mathrm{H} / \mathrm{I}^{\mathrm{a}}$ & $C_{t}^{b}$ & $\mathrm{Mb}$ & $\begin{array}{l}\text { No. of } \\
\text { reads }\end{array}$ & $\begin{array}{l}\text { No. of reads mapping to Xylella } \\
\text { fastidiosa }(\%)^{c}\end{array}$ \\
\hline Prunus amygdalus & I & 27.4 & 0.28 & 6,108 & $3,396(55.6)$ \\
\hline Rhamnus alaternus & I & NA & 0.44 & 9,462 & $28(0.3)$ \\
\hline Cystus sp. & 1 & 25.8 & 0.44 & 9,600 & $5,656(58.9)$ \\
\hline Rosmarinus officinalis & I & 35.1 & 0.29 & 6,228 & $2,178(35.0)$ \\
\hline Lavandula sp. & I & 28.8 & 1.19 & 25,798 & $10,391(40.3)$ \\
\hline Polygala myrtifolia & I & 25.1 & 0.51 & 11,085 & $7,065(63.7)$ \\
\hline Spartium junceum & I & 18.6 & 0.50 & 10,959 & $5,633(51.4)$ \\
\hline Prunus amygdalus & $\mathrm{H}$ & NA & NA & 5,620 & $0(0)$ \\
\hline Rhamnus alaternus & $\mathrm{H}$ & NA & NA & 3,718 & $0(0)$ \\
\hline Cystus sp. & $\mathrm{H}$ & NA & NA & 3,446 & $0(0)$ \\
\hline Rosmarinus officinalis & $\mathrm{H}$ & NA & NA & 5,857 & $0(0)$ \\
\hline Lavandula sp. & $\mathrm{H}$ & NA & NA & 3,895 & $0(0)$ \\
\hline Polygala myrtifolia & $\mathrm{H}$ & NA & NA & 3,487 & $0(0)$ \\
\hline
\end{tabular}

a, infected; $\mathrm{H}$, healthy.

${ }^{\mathrm{b}}$ Cycle threshold obtained by Francis et al. (2006), TaqMan version.

${ }^{\mathrm{c}}$ Percentage of reads mapped to $X$. fastidiosa over the number of total reads sequenced.

\section{3 | Identification of Xf ST using Nanopore amplicon sequencing}

It is generally accepted that the ST of Xf can be determined by assessing seven housekeeping genes (leuA, petC, malF, cysG, holC, nuoL, $g / t T$ ) in an MLST analysis (PM 7/24 (4)) (EPPO, 2019b). We therefore pursued typing the $\mathrm{Xf}$ infections based on these seven genes upon sequencing of PCR-generated amplicons. To this end, we first amplified DNA fragments using primer pairs for all housekeeping genes using, as template, DNA from Cystus sp., R. officinalis, and Lavandula sp. of Set 2 and subsequently sequenced them using Nanopore sequencing. The generated sequences were used to make consensus for all seven fragments for these plant species. Each fragment for all seven housekeeping genes for the same three plant samples was also Sanger sequenced. These plant species were selected because the ST of Xf had not previously been determined (Saponari et al., 2019). The consensus_script was used to generate a consensus sequence using only Nanopore reads. The script generated seven 


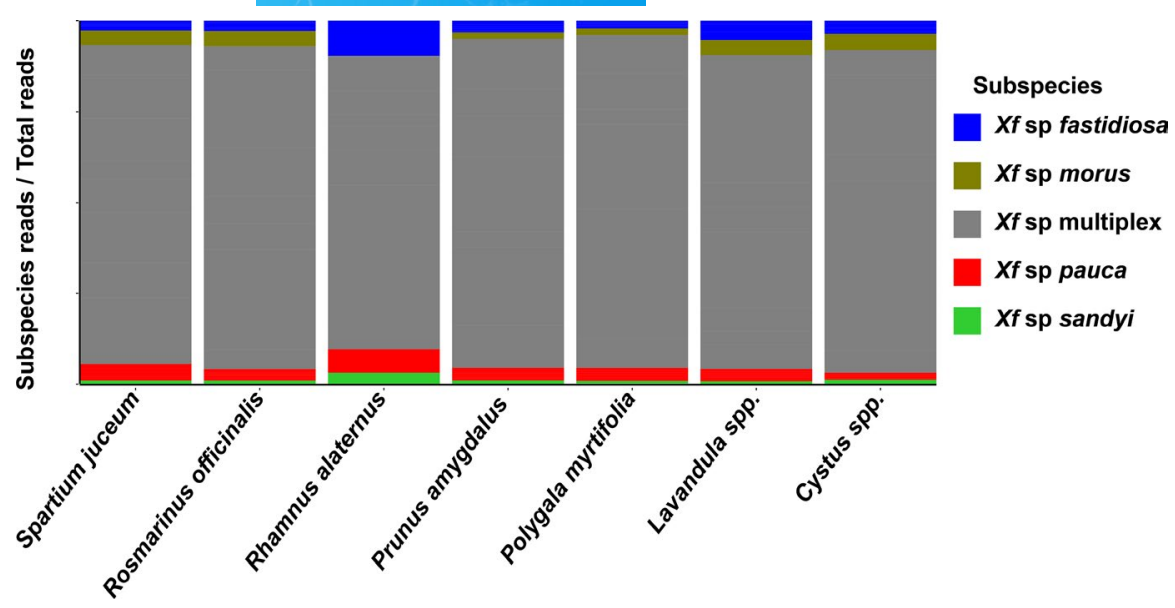

FIGURE 3 Stacked bar charts showing the relative abundance of different Xylella fastidiosa subspecies using the detection script on Nanopore amplicon sequencing of DNA from different plant species (Set 2). The most abundant subspecies is $X$. fastidiosa subsp. multiplex

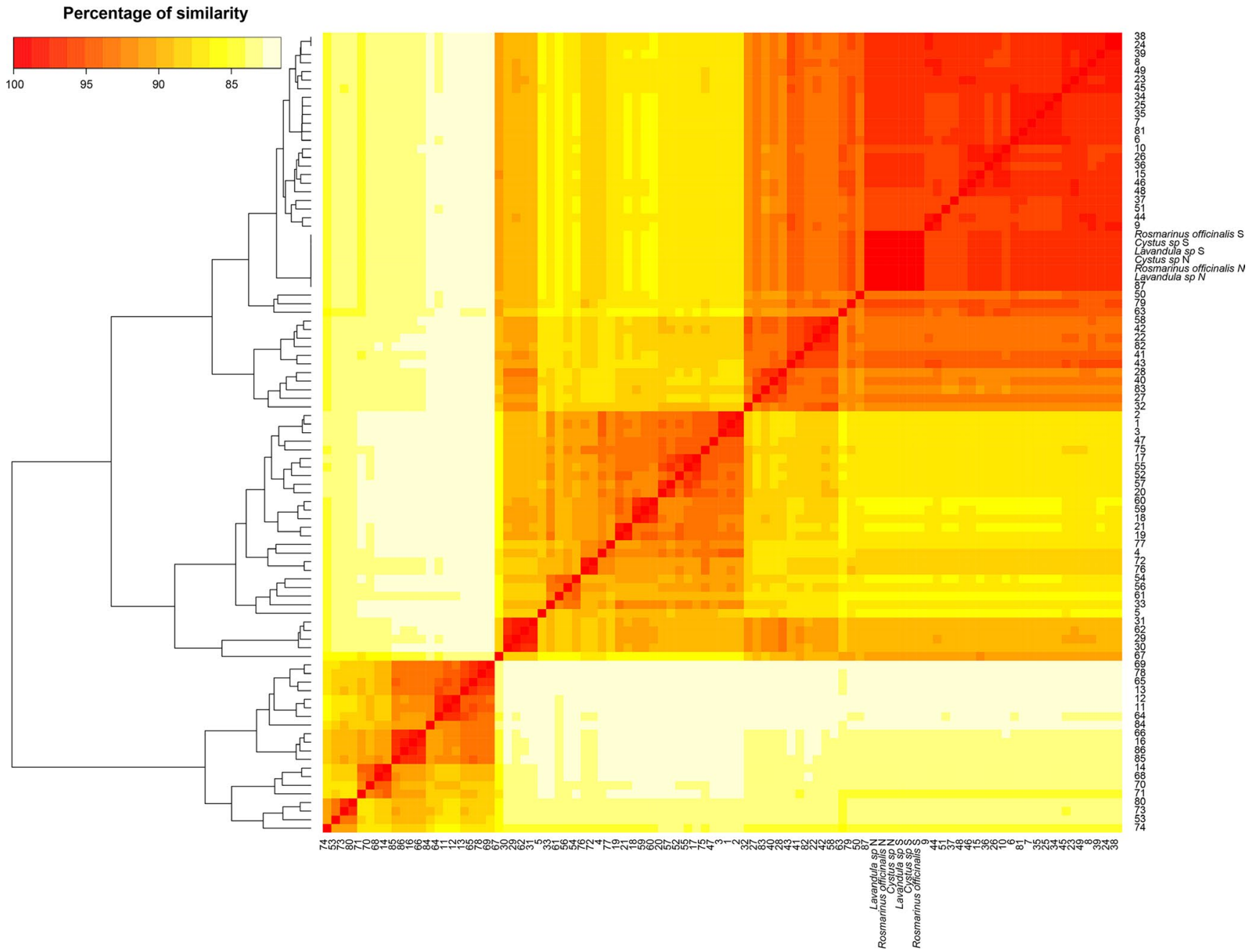

FIGURE 4 Heatmap representing sequence alignments of seven concatenated multilocus sequence typing (MLST) for 87 sequence types (STs) deposited at the MLST database (https://pubmlst.org), three sequences derived from Sanger sequencing of Rosmarinus officinalis, Cystus sp., and Lavandula sp., and three sequences derived from consensus of the Nanopore sequencing for R. officinalis, Cystus sp., and Lavandula sp. plant samples

sequences for each sample, one for each of the housekeeping genes, that were subsequently compared with the same sequences generated by Sanger technology (Yuan et al., 2010), followed by querying the database at https://pubmlst.org/organisms/xylella-fastidiosa
(Jolley et al., 2018). Pairwise alignment of concatenated sequences of all seven MLST derived from Sanger and Nanopore consensus revealed $100 \%$ identity (Figure 4), demonstrating the robustness of the Nanopore sequencing-based approach. Additionally, when the 
concatenated sequences derived from both Sanger and Nanopore sequencing were compared to the Xf MLST database, we found that samples of Cystus sp., $R$. officinalis, and Lavandula sp. showed the following MLST profile: leuA_5, petC_3, malF_5, cysG_3, holC_3, nuoL_21, gltT_3. The combination of the seven alleles corresponded to ST 87 (Figure 4), which is in agreement with recent findings of Xf ST 87 in P. amygdalus, P. myrtifolia, S. junceum, and R. alaternus (Saponari et al., 2019). Altogether, our data show that Nanopore amplicon sequencing can be used in infected plants to detect $\mathrm{Xf}$, and at the same time determine subspecies and ST.

\section{4 | DISCUSSION}

Over the last 15 years, NGS has transformed genomic research, being applied to genomics, transcriptomics, metagenomics, and diagnostics (Charalampous et al., 2019; Cook et al., 2019; Jain et al., 2018; Leggett et al., 2019). These technologies have recently been applied to the diagnosis of plant pathogens (Badial et al., 2018; Chalupowicz et al., 2019), including the detection and identification of Xf (Bonants et al., 2019). Although several diagnostic methods are available for the detection of Xf (EPPO, 2019b), the identification of subspecies and ST are currently laborious and time-consuming. Recently, a tetraplex real-time PCR assay was developed for simultaneous detection and identification of Xf subspecies in plant tissues (Dupas et al., 2019). The detection of Xf at subspecies level is fundamental, and in the case of new outbreaks or new plant hosts, the identification of the ST is strongly recommended (EPPO, 2019b).

To circumvent the complexity of the detection and identification of Xf subspecies and ST, we investigated the use of the ONT MinION device. One of the advantages of the MinION device compared to other NGS platforms is its portability. In this study, direct Nanopore DNA sequencing was assessed for the first time by using naturally infected plant samples (Sets 1 and 2). However, our results showed that the bacterium can only be reliably detected, and its subspecies identified, in samples with high levels of Xf. Every sample lacking reads mapping to the $X f$ genomes showed a high $C_{t}$ value in the realtime PCR that, associated with low sequencing throughput, made $\mathrm{Xf}$ undetectable. The lack of detection in samples with low DNA bacterial concentrations was confirmed by using artificially spiked olive samples with Xf DNA concentrations close to the limit of detection with real-time PCR (Set 3), which is currently considered the most sensitive assay for Xf detection (EPPO, 2019b; Modesti et al., 2017). Nanopore direct DNA sequencing of these samples provided only a low number of reads, resulting in an even lower number of reads mapping to $\mathrm{Xf}$ genomes, making the analysis questionable. $\mathrm{A}$ similar result was obtained by Bonants et al. (2019) using Illumina sequencing, as they reported the ability of NGS to determine the ST of Xf only in samples with high bacterial concentration. Moreover, Chalupowicz et al. (2019) discussed the applicability of Nanopore sequencing on artificially infected plant material with symptoms. They reasoned that Nanopore sequencing is applicable on heavily infected plant samples, where the pathogen:plant DNA ratio is relatively high, allowing the sequencing of pathogen DNA even with low throughput, suggesting a further investigation on symptomless plants. The low sensitivity of the direct Nanopore sequencing may be due to the low throughput generated for each sample, which can imply a low quality and quantity of the DNA in the tested samples. It is worth mentioning that Nanopore sequencing suffers from low throughput when the DNA used for the sequencing has contaminants and/or when the input DNA is made of short fragments (Chalupowicz et al., 2019). Further optimization of the DNA purification and addition of a size selection step may be necessary to maximize the performance of the Nanopore system. This aspect is of importance because Xf has a very broad host range and the DNA quality can be compromised by contaminants of the host matrix. Charalampous et al. (2019) developed a DNA extraction in order to deplete host DNA from the samples and thus enrich it for pathogen DNA. Using this approach, they were able to identify respiratory pathogens in human samples. However, carrying out massive analyses in practice is not compatible with time-consuming or expensive DNA purifications, as generally neither the DNA concentration, nor the DNA quality, are routinely determined in official analysis.

An alternative to employing sophisticated DNA extraction methodology is amplicon sequencing (Kilianski et al., 2015; Radhakrishnan et al., 2019). In our study this approach was assessed in order to overcome the low throughput of the flowcells and to set up a more reliable and sensitive detection method, based on the amplification of two housekeeping genes followed by Nanopore sequencing. Sequencing of cys $G$ and malF for subspecies discrimination is suggested (Dupas et al., 2019; EPPO, 2019b). Nanopore amplicon sequencing was efficacious for $\mathrm{Xf}$ detection of the spiked samples with low concentrations ( $<10 \mathrm{fg} / \mathrm{PCR}$ ) of $\mathrm{Xf}$ target DNA (Set 3 ). The addition of the amplification step, even though it makes the procedure longer, has several advantages: (a) reduction of the influence of poor DNA quality/quantity; (b) mitigation of sequencing errors by increased sequence depth; and (c) production of useful data faster than genomic DNA sequencing. The amplification step allows the detection of the pathogen as well as the identification of its subspecies and ST in a single sequencing step. The results of amplicon sequencing of Set 2 on S. junceum, P. myrtifolia, R. officinalis, Lavandula sp., $P$. amygdalus, and Cystus sp. confirmed previous findings that identified the subspecies multiplex in the plant infections (Marchi et al., 2018; Saponari et al., 2019). Moreover, amplicon sequencing performed on the seven MLST fragments in samples of R. officinalis, Cystus sp., and Lavandula sp. confirmed the recent findings that assigned the ST87 to the subsp. multiplex recovered in Tuscany (Saponari et al., 2019). The Nanopore amplicon sequencing workflow allows the detection of $\mathrm{Xf}$ and the identification of its subspecies and ST, producing the data output in a few hours and avoiding the time-consuming procedure required for Sanger sequencing of the two/seven housekeeping gene fragments (e.g., amplicon purification from agarose gel, Sanger sequencing, sequence purification, and comparison in data bank, analyses in the Xylella data bank for ST assignment). ST characterization is essential when an infection in a pest-free area or in a new plant species is detected. The ST determination can highlight 
possible recombination between strains that affect the evolution and adaptation to new plant hosts and suggest information on the origin of the strains (Coletta-Filho et al., 2017; Denancé et al., 2017; Scally et al., 2005).

The evidence obtained in this study shows that the sequencing of two or seven housekeeping genes by MinION is a reliable and robust method to detect and identify $\mathrm{Xf}$ from infected plant material, even with low bacterial concentrations, representing a powerful tool for a rapid Xf diagnosis. This approach is of interest for $X f$ detection in trade plants, and for latently infected material that represents one of the most serious threats for Xf dissemination. For an "in field" application, further studies are required to make direct Nanopore sequencing on genomic DNA reliable for detecting low DNA bacterial concentrations, for instance by using single flowcells for the processing of individual samples. This allows a greater depth of sequencing, and consequently a higher possibility of detection and identification of $\mathrm{Xf} /$ subspecies/ST. In conclusion, the results obtained in this study pave the way for novel opportunities for Nanopore sequencing as an effective surveillance tool for early, sensitive, reliable, and robust detection of $\mathrm{Xf}$ and other fastidious pathogens.

\section{ACKNOWLEDGEMENTS}

This work was supported by MIPAAFT, Project Oli. Di.X.I. It ("OLIvicoltura e Difesa da Xylella fastidiosa e da Insetti vettori in Italia"), D.M. 23773 del 6/09/2017 and by Project CO.XI.BO ("Controllo di parassiti e patogeni legati ad emergenze fitosanitarie: Xylosandrus compactus, Xylella fastidiosa, Botrytis cinerea"), D.M. 0037134 del 31/12/2018.

\section{DATA AVAILABILITY STATEMENT}

All data were deposited at the NCBI (https://www.ncbi.nlm.nih. gov/) under the accession number PRJNA575828 while all scripts used in the paper are deposited at https://github.com/Ifaino/xylella.

\section{ORCID}

Luigi Faino (D) https://orcid.org/0000-0002-6807-4191

Valeria Scala (D) https://orcid.org/0000-0001-9383-8766

Alessio Albanese (D) https://orcid.org/0000-0003-1783-5613

Vanessa Modesti (D) https://orcid.org/0000-0002-3435-4689

Alessandro Grottoli (D) https://orcid.org/0000-0001-9070-8747

Nicoletta Pucci (D) https://orcid.org/0000-0002-6563-1124

Andrea Doddi (D) https://orcid.org/0000-0003-3149-6304

Alessia L'Aurora (D) https://orcid.org/0000-0002-6698-6250

Giuseppe Tatulli (D) https://orcid.org/0000-0001-6257-1624

Massimo Reverberi (D) https://orcid.org/0000-0003-3671-6783

Stefania Loreti (D) https://orcid.org/0000-0001-7761-6186

\section{REFERENCES}

Bankevich, A., Nurk, S., Antipov, D., Gurevich, A.A., Dvorkin, M., Kulikov, A.S. et al. (2012) SPAdes: a new genome assembly algorithm and its applications to single-cell sequencing. Journal of Computational Biology, 19, 455-477.
Bonants, P., Griekspoor, Y., Houwers, I., Krijger, M., Van Der Zouwen, P., Van Der Lee, T.A.J. et al. (2019) Development and evaluation of a triplex taqman assay and next-generation sequence analysis for improved detection of Xylella in plant material. Plant Disease, 103, 645-655.

Bronzato Badial, A., Sherman, D., Stone, A., Gopakumar, A., Wilson, V., Schneider, W. et al. (2018) Nanopore sequencing as a surveillance tool for plant pathogens in plant and insect tissues. Plant Disease, 102, 1648-1652.

Bull, C.T., Coutinho, T.A., Denny, T.P., Firrao, G., Fischer-Le Saux, M., $\mathrm{Li}, \mathrm{X}$. et al. (2014) List of new names of plant pathogenic bacteria (2011-2012). Journal of Plant Pathology, 96, 223-226.

Chalupowicz, L., Dombrovsky, A., Gaba, V., Luria, N., Reuven, M., Beerman, A. et al. (2019) Diagnosis of plant diseases using the Nanopore sequencing platform. Plant Pathology, 68, 229-238.

Charalampous, T., Kay, G.L., Richardson, H., Aydin, A., Baldan, R., Jeanes, C. et al. (2019) Nanopore metagenomics enables rapid clinical diagnosis of bacterial lower respiratory infection. Nature Biotechnology, 37, 783-792.

Coletta-Filho, H.D., Francisco, C.S., Lopes, J.R.S., Muller, C. \& Almeida, R.P.P. (2017) Homologous recombination and Xylella fastidiosa host-pathogen associations in South America. Phytopathology, 107, 305-312.

Cook, D.E., Valle-Inclan, J.E., Pajoro, A., Rovenich, H., Thomma, B.P.H.J. \& Faino, L. (2019) Long-read annotation: automated eukaryotic genome annotation based on long-read cDNA sequencing. Plant Physiology, 179, 38-54.

Danecek, P. \& McCarthy, S.A. (2017) BCFtools/csq: haplotype-aware variant consequences. Bioinformatics, 33, 2037-2039.

Denancé, N., Briand, M., Gaborieau, R., Gaillard, S. \& Jacques, M.A. (2019) Identification of genetic relationships and subspecies signatures in Xylella fastidiosa. BMC Genomics, 20, 239.

Denancé, N., Legendre, B., Briand, M., Olivier, V., de Boisseson, C., Poliakoff, F., \& Jacques, M.-A. (2017) Several subspecies and sequence types are associated with the emergence of Xylella fastidiosa in natural settings in France. Plant Pathology, 66, 1054-1064.

Dupas, E., Briand, M., Jacques, M. \& Cesbron, S. (2019) Novel tetraplex qPCR assays for simultaneous detection and identification of Xylella fastidiosa subspecies in plant tissues. Frontiers in Plant Science, 10, 1732.

EPPO (2019a) First report of Xylella fastidiosa subsp. multiplex in Portugal. EPPO Reporting Service no. 01/2019. Article: 2019/017.

EPPO (2019b) PM 7/24 (4) Xylella fastidiosa. EPPO Bulletin, 49, 175-227.

Francis, M., Lin, H., La Rosa, J.C., Doddapaneni, H. \& Civerolo, E.L. (2006) Genome-based PCR primers for specific and sensitive detection and quantification of Xylella fastidiosa. European Journal of Plant Pathology, 115, 203-213.

Harper, S.J., Ward, L.I. \& Clover, G.R.G. (2010) Development of LAMP and real-time PCR methods for the rapid detection of Xylella fastidiosa for quarantine and field applications. Phytopathology, 100, 1282-1288.

Hopkins, D.L. (1989) Xylella fastidiosa: xylem-limited bacterial pathogen of plants. Annual Review of Phytopathology, 27, 271-290.

Jain, M., Koren, S., Miga, K.H., Quick, J., Rand, A.C., Sasani, T.A. et al. (2018) Nanopore sequencing and assembly of a human genome with ultra-long reads. Nature Biotechnology, 36, 338-345.

Jesus, J.G., Franco, L.C., Wu, C.-H., Baylis, S.A. \& Milagres, F.P. (2017) Epidemic establishment and cryptic transmission of Zika virus in Brazil and the Americas. bioRxiv, 546, 105171 [preprint].

Jolley, K.A., Bray, J.E. \& Maiden, M.C.J. (2018) Open-access bacterial population genomics: BIGSdb software, the PubMLST.org website and their applications [version 1; peer review: 2 approved]. Wellcome Open Research, 3, 124.

Kilianski, A., Haas, J.L., Corriveau, E.J., Liem, A.T., Willis, K.L., Kadavy, D.R. et al. (2015) Bacterial and viral identification and differentiation 
by amplicon sequencing on the MinION nanopore sequencer. Gigascience, 4, 12.

Landa, B. (2017) Emergence of Xylella fastidiosa in Spain: current situation. In: European Conference on Xylella fastidiosa 2017. European Food Safety Authority. Available from: https://www.efsa.europa.eu/sites/default/files/event/171113/171113-1.3_Landa.pdf [Accessed 17 January 2019].

Leggett, R.M., Alcon-Giner, C., Heavens, D., Caim, S., Brook, T.C., Kujawska, M. et al. (2019) Rapid MinION profiling of preterm microbiota and antimicrobial-resistant pathogens. Nature Microbiology, 5 , 430-442.

Li, H. (2018) Minimap2: pairwise alignment for nucleotide sequences. Bioinformatics, 34, 3094-3100.

Li, W., Teixeira, D.C., Hartung, J.S., Huang, Q.i., Duan, Y., Zhou, L. et al. (2013) Development and systematic validation of qPCR assays for rapid and reliable differentiation of Xylella fastidiosa strains causing citrus variegated chlorosis. Journal of Microbiological Methods, 92, 79-89.

Loreti, S., Pucci, N., Loconsole, G., Modesti, V., Lucchesi, S., Potere, O., et al. (2017) Protocollo diagnostico per Xylella fastidiosa subsp. pauca ceppo CoDiRO. In: Barba, M., Belisario, A., Faggioli, F., Ferretti, L., Gentili, A., Haegi, A., Ilardi, V., Loreti, S., Pucci, N., Riccioni, L., Scala, V. \& Vitale, S. (Eds.), Protocolli di diagnosi di riferimento P.F. "ASPROPI". ASPROPI. Rome, Italy: CREA, pp. 241-278.

Marçais, G. \& Kingsford, C. (2011) A fast, lock-free approach for efficient parallel counting of occurrences of k-mers. Bioinformatics, 27, 764-770.

Marcelletti, S. \& Scortichini, M. (2016) Genome-wide comparison and taxonomic relatedness of multiple Xylella fastidiosa strains reveal the occurrence of three subspecies and a new Xylella species. Archives of Microbiology, 198, 803-812.

Marchi, G., Rizzo, D., Ranaldi, F., Ghelardini, L., Ricciolini, M., Scarpelli, I. et al. (2018) First detection of Xylella fastidiosa subsp. multiplex DNA in Tuscany (Italy). Phytopathologia Mediterranea, 57, 363-364.

Modesti, V., Pucci, N., Lucchesi, S., Campus, L. \& Loreti, S. (2017) Experience of the Latium region (central Italy) as a pest-free area for monitoring of Xylella fastidiosa: distinctive features of molecular diagnostic methods. European Journal of Plant Pathology, 148, 557-566.

Nunney, L., Elfekih, S. \& Stouthamer, R. (2012) The importance of multilocus sequence typing: cautionary tales from the bacterium Xylella fastidiosa. Phytopathology, 102, 456-462.

Olmo, D., Nieto, A., Adrover, F., Urbano, A., Beidas, O., Juan, A. et al. (2017) First detection of Xylella fastidiosa infecting cherry (Prunus avium) and Polygala myrtifolia plants in Mallorca Island Spain. Plant Disease, 101, 1820.

Page, A.J. \& Keane, J.A. (2018) Rapid multi-locus sequence typing direct from uncorrected long reads using Krocus. PeerJ, 2018, e5233.

Radhakrishnan, G.V., Cook, N.M., Bueno-Sancho, V., Lewis, C.M., Persoons, A., Mitiku, A.D. et al. (2019) MARPLE, a point-of-care, strain-level disease diagnostics and surveillance tool for complex fungal pathogens. BMC Biology, 17, 65.

Saponari, M., Boscia, D., Nigro, F. \& Martelli, G.P. (2013) Identification of DNA sequences related to Xylella fastidiosa in oleander, almond and olive trees exhibiting leaf scorch symptoms in Apulia (southern Italy). Journal of Plant Pathology, 95, 668.

Saponari, M., D'Attoma, G., Abou Kubaa, R., Loconsole, G., Altamura, G., Zicca, S. et al. (2019) A new variant of Xylella fastidiosa subspecies multiplex detected in different host plants in the recently emerged outbreak in the region of Tuscany, Italy. European Journal of Plant Pathology, 154, 1195-1200.

Saponari, M. \& Loconsole, G. (2018) TEST PERFORMANCE STUDY. Molecular detection of Xylella fastidiosa through quantitative real time assays. Implementation of the Proficiency test EU-XF- PT2017-02. Available from: https://www.ponteproject.eu/wp-conte nt-uploads-2017-07-eu-xf-pt-2017-02-results-zip/ [Accessed 28 May 2021].

Scally, M., Schuenzel, E.L., Stouthamer, R. \& Nunney, L. (2005) Multilocus sequence type system for the plant pathogen Xylella fastidiosa and relative contributions of recombination and point mutation to clonal diversity. Applied and Environmental Microbiology, 71, 8491-8499.

Schaad, N.W., Postnikova, E., Lacy, G., Fatmi, M.B. \& Chang, C.J. (2004) Xylella fastidiosa subspecies: $X$. fastidiosa subsp. fastidiosa [corrected], subsp. nov $X$. fastidiosa subsp. multiplex subsp. nov. and $X$. fastidiosa subsp. pauca subsp. nov. Systematic and Applied Microbiology, 27, 290-300. [Subsp. piercei corrected by subsp. fastidiosa in Systematic and Applied Microbiology 27: 763.]

Scortichini, M., Chen, J., de Caroli, M., Dalessandro, G., Pucci, N., Modesti, V. et al. (2018) A. zinc, copper and citric acid biocomplex shows promise for control of Xylella fastidiosa subsp. pauca in olive trees in Apulia region (southern Italy). Phytopathologia Mediterranea, 57, 48-72.

Sherald, J. \& Kostka, S. (1992) Bacterial leaf scorch of landscape trees caused by Xylella fastidiosa. Journal of Arboriculture, 18, 57-63.

Vaser, R., Sović, I., Nagarajan, N. \& Šikić, M. (2017) Fast and accurate de novo genome assembly from long uncorrected reads. Genome Research, 27, 737-746.

Votintseva, A.A., Bradley, P., Pankhurst, L., del Ojo Elias, C., Loose, M., Nilgiriwala, K. et al. (2017) Same-day diagnostic and surveillance data for tuberculosis via whole-genome sequencing of direct respiratory samples. Journal of Clinical Microbiology, 55, 1285-1298.

Wells, J.M., Raju, B.C., Hung, H.-Y., Weisburg, W.G., Mandelco-Paul, L. \& Brenner, D.J. (1987) Xylella fastidiosa gen. nov., sp. nov: gram-negative, xylem-limited, fastidious plant bacteria related to Xanthomonas spp. International Journal of Systematic Bacteriology, 37, 136-143.

Wick, R.R., Judd, L.M. \& Holt, K.E. (2018) Deepbinner: demultiplexing barcoded OXford Nanopore reads with deep convolutional neural networks. PLoS Computational Biology, 14, e1006583.

Wick, R.R., Judd, L.M. \& Holt, K.E. (2019) Performance of neural network basecalling tools for OXford Nanopore sequencing. Genome Biology, 20, 129.

Yuan, X., Morano, L., Bromley, R., Spring-Pearson, S., Stouthamer, R. \& Nunney, L. (2010) Multilocus sequence typing of Xylella fastidiosa causing Pierce's disease and oleander leaf scorch in the United States. Phytopathology, 100, 601-611.

How to cite this article: Faino, L., Scala, V., Albanese, A., Modesti, V., Grottoli, A., Pucci, N., et al (2021) Nanopore sequencing for the detection and identification of Xylella fastidiosa subspecies and sequence types from naturally infected plant material. Plant Pathology, 00, 1-11. https://doi. org/10.1111/ppa.13416 